\title{
PHYSICAL ACTIVITY OF SECONDARY AND PERFORMING ARTS HIGH SCHOOL STUDENTS IN RELATION TO PHYSICAL EDUCATION ASSESSMENT
}

\author{
Živilė Gadliauskaité丶 ${ }^{1}$, Asta IgarienÉ2, \\ Rita Gruodyté-RaČIEnÉ ${ }^{1}$ \\ ${ }^{1}$ Lithuanian Sports University, Kaunas, Lithuania \\ ${ }^{2}$ Kaunas Old Town Progymnasium, Kaunas, Lithuania
}

\begin{abstract}
The aim of this study was to assess whether the way of evaluation in Physical Education (PE) classes (i.e. by a mark or being credited as 'pass' or ' $f a i l$ ') is associated with physical activity (PA) of high school students, and whether there are differences if students are of secondary or performing arts high school. The study involved 486 students of $9-12^{\text {th }}$ grades from three secondary and three performing arts high schools in one of the biggest cities of Lithuania. Analyzing secondary high school students' PA, estimated by modified International PA Questionnaire, in relation to assessment system in $\mathrm{PE}$, statistically significant $(\mathrm{p}<0.01)$ differences were found only in vigorous PA (VPA), i.e. students, who are assessed by marks in PE, are involved in VPA more frequently than those who are being rated 'pass' or 'fail'. A reverse situation was observed in performing arts high school students: more students, who are being rated 'pass' or 'fail' in PE, are involved in vigorous and moderate PA more frequently comparing to students who are assessed by a mark. We may conclude that the assessment mode in PE classes may influence PA of schoolchildren, but differently for secondary and performing arts high school students.
\end{abstract}

Keywords: adolescents; performing arts; physical activity; physical education 


\section{INTRODUCTION}

The main aim of Physical Education (PE) as a subject is not only to develop physical abilities and motor skills of schoolchildren, but also their physical literacy as well as embodying knowledge on lifetime physical activity promotion [23]. The evaluation of students' progress and achievement in $\mathrm{PE}$ is an object of constant debates among teachers and communities of secondary schools as well as scientists: what to evaluate (innate abilities of students; the progress made and achievements; tactics and/or technical actions; readiness for a lesson; or non-formal educational achievements)?; how to evaluate (a mark vs. pass/fail)?; how, while assessing, to maintain positive communication and cooperation between a student and a teacher?; how to encourage student by assessment?; and what are the views of the students the recipients of PE at school? $[8,11,13,21]$. The number of research conducted in the world $[22,24]$ and Lithuania $[6,10,20,25,27]$ indicates that evaluation of secondary school students' academic achievements is a relevant issue in education. General education plans of Middle and High School curriculum in Lithuania [16] states that students' achievement in PE lessons may be evaluated either by mark or by pass/fail system, and that it is optional depending on what the council of each school chooses. There is also an opportunity for students to decide how they want to be assessed in PE lessons - by mark or by pass/fail system; but it is recommended to evaluate the achievements by marks if the student plans to study sport sciences in the university [16]. For example, children in Canada and Japan value assessment by marks in PE lessons as essential and necessary [23].

Physical activity (PA) is one of the influencing longevity factors associated with physical fitness, health, and independence in everyday life [2]. Children, who are physically active, are stronger and more physically capable than their inactive peers; but despite the benefits, physical activity of many Lithuanian children (as well as around the world) is insufficient $[1,12,31]$. Lack of PA during growing years negatively affects child's body and its functions, and gives birth to indolence, heaviness, and apathy [1,2]. Scientific research reveals the links between physical activity and better academic performance of children and adolescents [7]. Physical activity positively affects their brain activity, i.e. such cognitive functions as memory, attention and information processing, as well as problem-solving skills $[5,7,9]$. Physical activity improves pupils' social and communication skills, teamwork, increases their self-confidence [5]. World Health Organization (WHO) recommends that children and adolescents allocate at least 60 minutes of moderate to vigorous physical activity (MVPA) daily [29]. However, studies 
show that most of the free time they dedicate for watching TV, playing computer games, or other passive recreation forms [14].

Unfortunately, there is a lack of scientific evidence on PA in a specific group of children and adolescents, i.e. the ones who are engaged in numerous hours of artistic (performing arts) activities during their everyday life. Professional artists (especially musicians) experience a variety of positions (sitting or standing) for prolonged time that may not be of ergonomic nature and may lead to musculoskeletal problems [15]. Regional muscle pain syndromes (particularly of the upper limb, upper trunk, and neck), peripheral nerve disorders (including thoracic outlet syndrome, ulnar neuropathy at the elbow, and carpal tunnel syndrome), and postural abnormalities (caused by increased muscle tension in the neck and shoulders, scoliosis, kyphosis, leg-length discrepancy, and lack of spinal mobility) are the most common neuromuscular and musculoskeletal problems of instrumental musicians $[17,28]$. Musculoskeletal pain in various body parts of instrumentalists already commence at such a young age as $10-18$ years [18]. It is not a single acute injury that typically causes health problems for an artist, but rather a result of the confluence of many risk factors (e.g. for musicians it may include the particular instrument, players' gender, hand size, joint properties, the duration and intensity of playing, a mismatch between the musician's body and the instrument, improper technique, etc.) [3, 4, 28]. In the treatment of health disorders and ailments of an artist, physical activity plays a crucial role: strength, endurance and flexibility for the musician may be of high importance since playing a musical instrument requires huge physical and mental exertions [28, 30].

The aim of this study was to investigate physical activity of the secondary and performing arts high school students in relation to PE assessment mode (i.e. by a mark or being credited as 'pass' or 'fail').

\section{MATERIALS AND METHODS}

\section{Subjects}

This cross-sectional study involved 486 students of 9-12 ${ }^{\text {th }}$ grades (boys and girls aged 14-18-years) from three secondary and three performing arts high schools in one of the biggest cities of Lithuania. Five of those schools were selected purposively, i.e. all of the existing performing arts high schools in this particular city $(\mathrm{n}=3)$, and two secondary high schools - the only ones that had a "pass/fail" evaluation in PE in the same city. The other secondary school (where achievements in PE were marked by grades) was 
selected on convenience principle, based on the agreement from the school administration to participate in this study. In two performing arts (as well as already mentioned two secondary) high schools a "pass/fail“ system has been chosen for the evaluation of student achievements in PE lessons. The specificity of the performing arts high schools is that students, besides the general secondary education programme, receive a specialized curriculum of their chosen arts or music. It means that every school day they have 7-8 lessons of secondary education curriculum plus approx. 4-6 or more hours of specialized performing arts curriculum (including time for practice and self-study).

\section{Procedure}

The survey of 18 questions was used to assess students' PA [26] and investigate their viewpoint on evaluation of their progress and achievements in $\mathrm{PE}$ lessons [8]. The frequency of moderate and vigorous PA as well as walking that lasted at least for 10 consecutive minutes during the last seven days of schoolchildren was determined using the modified short self-administered form of the international physical activity questionnaire (IPAQ) in Lithuanian language $[26,31]$. The approval of the schools' administration as well as informed consent of students who volunteered to participate in this study was obtained. Respondents were introduced with study purpose, questionnaire content, it's filling process, and informed about the right to resign from the survey at any moment.

\section{Statistical analysis}

A questionnaire data was processed using the percentage analysis of the responses. Group comparison was made by calculating $\chi^{2}$ (chi-square) criteria. Statistical data analysis was performed using SPSS (Statistical Package for Social Sciences) software package for Windows (version 20.0). Statistical significance was set at $\mathrm{p}<0.05$.

\section{RESULTS}

Comparing secondary high school students' PA with that of their peers from performing arts high school, statistically significant $(\mathrm{p}<0.01)$ differences were found in moderate and vigorous PA (Table 1). About one fourth of secondary high school and almost half of the performing arts high school students (26.4\% vs. $46.7 \%$, respectively) were engaged in VPA for 1-2 days/week. But regarding VPA frequency of 5-7 days/week, twice as more 
students from secondary high school than from performing arts high school were engaged in it ( $28.9 \%$ vs. $11.1 \%$, respectively). Similar tendency was observed in moderate PA (MPA) frequency - performing arts high school students were less often engaged in MPA than their counterparts from secondary high school. There were no statistically significant differences in low intensity PA, i.e. walking (Table 1).

Table 1. Students' physical activity frequency according to the type of school (n / \%).

\begin{tabular}{|c|c|c|c|c|c|c|}
\hline \multirow[t]{2}{*}{$\begin{array}{l}\text { Physical } \\
\text { activity }\end{array}$} & \multicolumn{3}{|c|}{$\begin{array}{l}\text { Secondary high school } \\
\text { students }(n=242)\end{array}$} & \multicolumn{3}{|c|}{$\begin{array}{l}\text { Performing arts high school } \\
\text { students }(n=244)\end{array}$} \\
\hline & $1-2$ days & $3-4$ days & 5-7 days & $1-2$ days & $3-4$ days & $5-7$ days \\
\hline \multirow{2}{*}{$\begin{array}{l}\text { During the } \\
\text { last } 7 \text { days } \\
\text { engaged in VPA }\end{array}$} & 64 / 26.4 & $108 / 44.6$ & $70 / 28.9$ & $114 / 46.7$ & $103 / 42.2$ & $27 / 11.1$ \\
\hline & \multicolumn{6}{|c|}{$x^{2}=33.218 ; d f=2 ; p=0.000$} \\
\hline \multirow{2}{*}{$\begin{array}{l}\text { During the } \\
\text { last } 7 \text { days } \\
\text { engaged in MPA }\end{array}$} & $67 / 27.7$ & $112 / 46.3$ & $63 / 28.9$ & $111 / 45.5$ & $89 / 36.5$ & $44 / 18.0$ \\
\hline & \multicolumn{6}{|c|}{$X^{2}=18.274 ; d f=3 ; p=0.000$} \\
\hline \multirow{2}{*}{$\begin{array}{l}\text { During the last } \\
7 \text { days spent } \\
\text { walking (LPA) }\end{array}$} & $21 / 8.7$ & $69 / 28.5$ & $152 / 62.8$ & $33 / 13.5$ & $51 / 20.9$ & $160 / 65.6$ \\
\hline & \multicolumn{6}{|c|}{$x^{2}=7.086 ; d f=3 ; p=0.069$} \\
\hline
\end{tabular}

Note: VPA - vigorous physical activity; MPA - moderate physical activity; LPA - low physical activity

The frequency of PA of secondary and performing arts high school students according to the mode of the assessment in PE is presented in Table 2. Statistically significant differences were found only in MPA frequency: the majority of students, who were assessed by pass/fail in PE, during the last 7 days were engaged in MPA more frequently (i.e. for 3-4 days/week) in comparison to the students, who were assessed by mark, the majority of which were engaged in MPA for 1-2 days/week only.

When analyzing students' PA in relation to the assessment mode in PE separately by the school type, for the majority of students of secondary high schools VPA frequency was the same - 3-4 days/week for both assessed by mark and by pass/fail system (Table 3 ). Nevertheless, statistically significant $(p<0.01)$ differences were found in other VPA frequency groups, i.e. students, who are assessed by marks in PE, were involved in vigorous PA more frequently ( $46.5 \%$ vs. $36.0 \%$ of the respondents dedicate $3-4$ vs. $5-7$ days/week for VPA, respectively) than those who are being rated pass/fail in PE (42.9\% vs. $34.5 \%$ of the respondents dedicate $3-4$ vs. $1-2$ days/week for VPA, respectively). 
Table 2. Students' physical activity frequency according to the mode of assessment in physical education (PE) ( $\mathrm{n} / \%)$.

\begin{tabular}{|c|c|c|c|c|c|c|}
\hline \multirow{3}{*}{$\begin{array}{l}\text { Physical } \\
\text { activity }\end{array}$} & \multicolumn{6}{|c|}{ Assessment in PE } \\
\hline & \multicolumn{3}{|c|}{ By mark $(n=211)$} & \multicolumn{3}{|c|}{ By pass/fail system $(n=275)$} \\
\hline & $1-2$ days & $3-4$ days & $5-7$ days & $1-2$ days & $3-4$ days & $5-7$ days \\
\hline \multirow{2}{*}{$\begin{array}{l}\text { During the last } \\
7 \text { days engaged } \\
\text { in VPA }\end{array}$} & $72 / 34.1$ & $95 / 45.0$ & $44 / 20.9$ & $106 / 38.5$ & $116 / 42.2$ & $53 / 19.3$ \\
\hline & \multicolumn{6}{|c|}{$X^{2}=1.009 ; d f=2 ; p=0.604$} \\
\hline \multirow{2}{*}{$\begin{array}{l}\text { During the last } \\
7 \text { days engaged } \\
\text { in MPA }\end{array}$} & $88 / 41.7$ & $73 / 34.6$ & $50 / 23.7$ & $90 / 32.7$ & $128 / 46.6$ & $57 / 20.7$ \\
\hline & \multicolumn{6}{|c|}{$x^{2}=7.228 ; d f=2 ; p=0.027$} \\
\hline \multirow{2}{*}{$\begin{array}{l}\text { During the last } \\
7 \text { days spent } \\
\text { walking (LPA) }\end{array}$} & $24 / 11.4$ & $56 / 26.5$ & $131 / 62.1$ & $29 / 10.5$ & $64 / 23.3$ & $182 / 66.2$ \\
\hline & \multicolumn{6}{|c|}{$X^{2}=0.903 ; d f=2 ; p=0.637$} \\
\hline
\end{tabular}

Note: VPA - vigorous physical activity; MPA - moderate physical activity; LPA - low physical activity

Table 3. Secondary high school students' physical activity frequency according to the mode of assessment in physical education (PE) ( $n / \%)$.

\begin{tabular}{|c|c|c|c|c|c|c|}
\hline \multirow{3}{*}{$\begin{array}{l}\text { Physical } \\
\text { activity }\end{array}$} & \multicolumn{6}{|c|}{ Secondary high school assessment in PE } \\
\hline & \multicolumn{3}{|c|}{ Mark $(n=114)$} & \multicolumn{3}{|c|}{ Pass/Fail system ( $n=128)$} \\
\hline & $1-2$ days & $3-4$ days & $5-7$ days & $1-2$ days & $3-4$ days & $5-7$ days \\
\hline \multirow{2}{*}{$\begin{array}{l}\text { During the last } \\
7 \text { days engaged } \\
\text { in VPA }\end{array}$} & $20 / 17.5$ & $53 / 46.5$ & $41 / 36.0$ & $44 / 34.5$ & $55 / 42.9$ & $29 / 22.6$ \\
\hline & \multicolumn{6}{|c|}{$X^{2}=10.319 ; d f=2 ; p=0.006$} \\
\hline \multirow{2}{*}{$\begin{array}{l}\text { During the last } \\
7 \text { days engaged } \\
\text { in MPA }\end{array}$} & $33 / 28.9$ & $46 / 40.4$ & $35 / 30.7$ & $34 / 26.6$ & $66 / 51.5$ & $28 / 21.9$ \\
\hline & \multicolumn{6}{|c|}{$x^{2}=3.566 ; d f=2 ; p=0.168$} \\
\hline \multirow{2}{*}{$\begin{array}{l}\text { During the last } \\
7 \text { days spent } \\
\text { walking (LPA) }\end{array}$} & $9 / 7.9$ & $35 / 30.7$ & $70 / 61.4$ & $12 / 9.4$ & $34 / 26.6$ & $82 / 64.0$ \\
\hline & \multicolumn{6}{|c|}{$x^{2}=1.958 ; d f=3 ; p=0.581$} \\
\hline
\end{tabular}

Note: VPA - vigorous physical activity; MPA - moderate physical activity; LPA - low physical activity

A reverse situation was observed in performing arts high school students: more students, who were being rated pass/fail in PE, were involved in vigorous and moderate PA more frequently comparing to students who were being assessed by a mark: $16.3 \%$ vs. $3.1 \%$ dedicate 5-7 days/week for VPA, respectively ( $<<0.01$ ); and $42.2 \%$ vs. $27.8 \%$ dedicate $3-4$ days/week for MPA, respectively $(\mathrm{p}<0.05)$ (Table 4$)$. 
Table 4. Performing arts high school students' physical activity frequency according to the mode of assessment in physical education (PE) ( $n / \%)$.

\begin{tabular}{lllllll}
\hline \multirow{2}{*}{$\begin{array}{l}\text { Physical } \\
\text { activity }\end{array}$} & \multicolumn{5}{c}{ Performing arts high school assessment in PE } \\
\cline { 2 - 6 } & \multicolumn{5}{c}{ Mark ( $\mathrm{n}=97)$} & \multicolumn{3}{c}{ Pass/Fail system ( $\mathrm{n}=147)$} \\
\cline { 2 - 6 } & $1-2$ days & $3-4$ days & $5-7$ days & $1-2$ days & $3-4$ days & $5-7$ days \\
\hline $\begin{array}{l}\text { During the last } \\
7 \text { days engaged } \\
\text { in VPA }\end{array}$ & $52 / 53.6$ & $42 / 43.3$ & $3 / 3.1$ & $62 / 42.2$ & $61 / 41.5$ & $24 / 16.3$ \\
\cline { 2 - 6 } $\begin{array}{l}\text { During the last } \\
7 \text { days engaged } \\
\text { in MPA }\end{array}$ & $55 / 56.7$ & $27 / 27.8$ & $15 / 15.5$ & $56 / 38.1$ & $62 / 42.2$ & $29 / 19.7$ \\
\hline $\begin{array}{l}\text { During the last } \\
7 \text { days spent } \\
\text { walking (LPA) }\end{array}$ & $16 / 16.5$ & $21 / 21.6$ & $60 / 61.9$ & $17 / 11.6$ & $30 / 20.4$ & $100 / 68.0$ \\
\cline { 2 - 6 } & \multicolumn{5}{c}{$x^{2}=10.928 ; d f=2 ; p=0.004$} \\
\hline
\end{tabular}

Note: VPA - vigorous physical activity; MPA - moderate physical activity; LPA - low physical activity.

Secondary and performing arts high school students' opinion about the mode of assessment to be used in PE (i.e. whether they want to be evaluated by mark, by „pass/fail“, or not assessed at all) with respect to the current evaluation system is presented in Figure 1. The majority (59.6\%) of secondary high school students, currently assessed by mark in PE lessons, wish to be evaluated by mark; while the majority (58.6\%) of secondary high school students, currently assessed by „pass/fail“ in PE lessons, wish to be assessed by „pass/fail“ ( $\mathrm{p}<0.001)$. Completely different situation was observed in performing arts high school students: the majority (46.4\%) of those assessed by mark in PE lessons want to be assessed by "pass/fail"; and the majority (42.2\%) of those who were assessed by "pass/fail" wish to be not assessed at all during PE lessons $(\mathrm{p}<0.001)$ (Figure 1).

Evaluating the importance of the assessment in PE, most of the students regardless the type of the high school (i.e. secondary or performing arts) and the mode of the assessment in PE (i.e. by mark or by pass/fail) indicated that they study mainly for the sake of themselves and not for the marks or other reasons such as not wanting to lag behind the classmates or that the assessment is more important to their parents $(\mathrm{p}<0.05)$ (Figure 2$)$. 


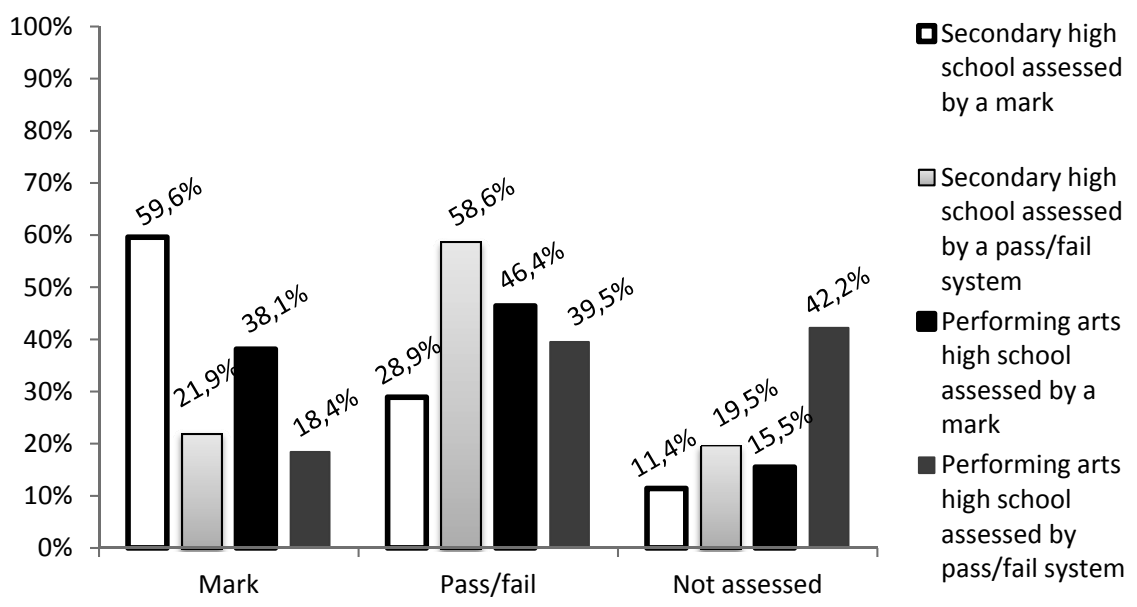

Figure 1. Students' opinion about the preferable mode of assessment in PE (i.e. by mark, by "pass/fail", or not assessed at all) with respect to the existing evaluation system and type of school (differences within the type of school, $p<0.001$ ).

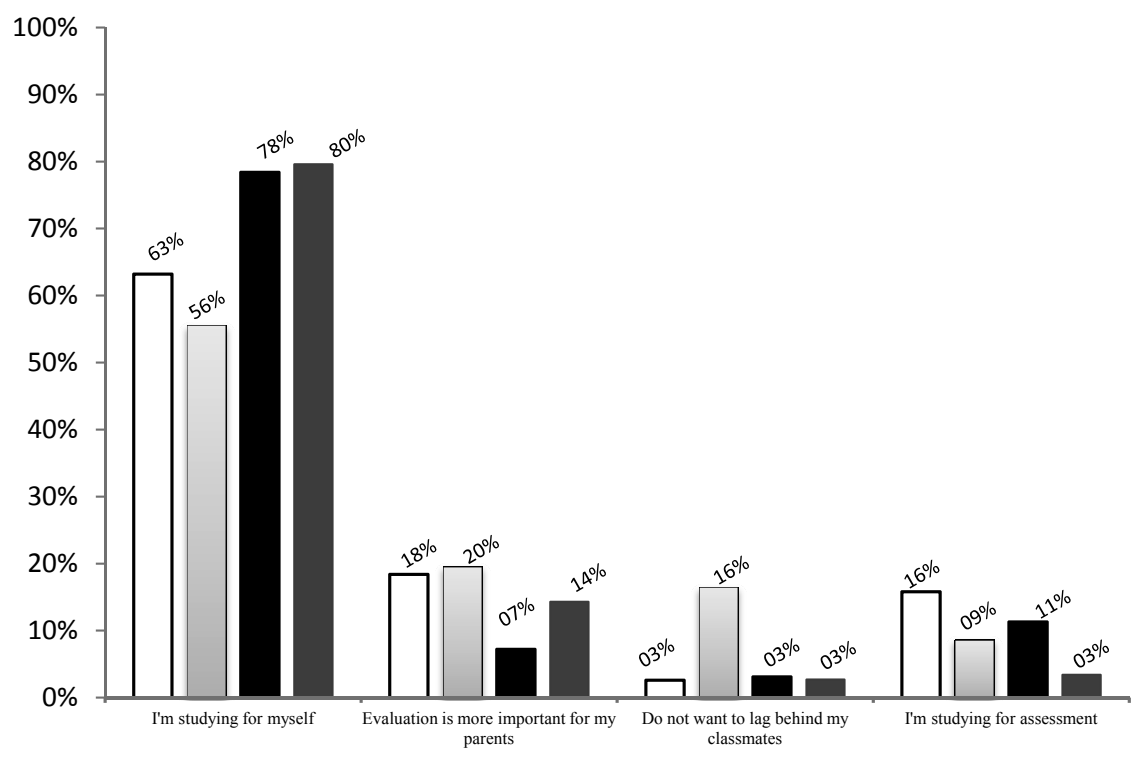

口Secondary high school assessed by a mark

$\square$ Secondary high school assessed by pass/fail system

- Performing arts high school assessed by a mark

- Performing arts high school assessed by pass/fail system

Figure 2. The importance of evaluation in PE for students (differences within the type of school, $\mathrm{p}<0.05)$. 


\section{DISCUSSION}

We aimed to investigate PA of 14-18-year-old students from secondary and performing arts high schools in relation to the existing assessment mode used in PE lessons in their respective schools. Secondary high school students, in general, were more active than their peers from performing arts high schools (see Table 1). Peculiar situation was observed regarding students' PA associated with assessment mode in PE: in secondary schools the ones who were assessed by mark were engaged in VPA more often than those who were assessed by pass/fail $(\mathrm{p}<0.001)$; however, in performing arts high schools those who were assessed by mark were less engaged in MPA and VPA than those who were assessed by pass/fail system $(\mathrm{p}<0.05)$ (see Tables $3 \& 4$ ). According to WHO recommendations [29], children and adolescents should engage in MVPA for at least 1 hour every day. Although our research methodology did not allow us to identify the exact number of students matched the WHO recommended PA dose, the study found that less than one third of students, both from secondary and performing arts high schools, and regardless whether they were evaluated by mark or by pass/fail system in PE, were daily engaged in MVPA (see Tables 1-4). Studies claim that on average only every second boy and every fifth girl of adolescent age in Lithuania are considered to be physically active sufficiently [31].

Unfortunately, there are no known studies that attempt to systematically examine the PA and health-related consequences of prolonged artistic activities among performing arts high school students in Lithuania. Nawrocka et al. [18] indicate that early prophylaxis of playing-related musculoskeletal disorders is already needed among young musicians-instrumentalists. Musculoskeletal problems are frequent not only among professional artists but also among so called „serious amateurs" [4]. In order to manage injuries caused by the tissue overload and overuse, a relative rest in both musical and routine daily activities is of vital importance [28]. This rest period may be quite challenging because of the performing artists' commitments to constant practice, auditions and recitals, even at a young age. Therefore, therapeutic exercises such as postural correction, periscapular strengthening, and stretching of neck and shoulder muscles [28] should be focused on during PE lessons and practiced on a habitual basis to help alleviate many musculoskeletal problems in adolescents studying in specialized performing arts high schools.

According to our survey data, the majority of secondary high school students are contented with the existing evaluation mode in PE, i.e. who are being assessed by marks in PE would like to be assessed by marks (59.6\%); 
as well as students who are assessed by pass/fail system would like to be assessed by pass/fail system (58.6\%). However, performing arts high school students who are assessed by marks would like to be assessed by pass/fail system (46.4\%), and those students who are assessed by pass/fail system wish to be not assessed at all (42.2\%). To study for the sake of themselves and not for the marks in PE indicated the majority of the respondents regardless the type of school and the mode of the assessment used in PE lessons. This corresponds well with the data found in another study [8], were almost half of the students of the same age as our study subjects also value learning for their own sake and not for evaluation. This sets on an optimistic note that the goal [16] and the idea of modern physical education [19] - to instil the need for lifetime physical activity - brought the first results.

We may conclude that assessment in PE is associated with secondary and performing arts high school students' PA. Secondary high school students who were assessed by mark were engaged in VPA more often than those who were assessed by pass/fail system. However, a reverse situation was observed in performing arts high school students, i.e. those who were assessed by mark were less engaged in MVPA than those who were assessed by pass/ fail system. The majority of secondary high school students were satisfied with the current assessment mode in PE, while performing arts high school students prefer to either be assessed by pass/fail system or to be not assessed at all. In general, secondary high school students were more physically active than their peers from performing arts high schools, although not even one third of all the respondents were active sufficiently. It implicates the necessity of effective physical activity intervention programmes, especially in specialized performing arts high schools, to prevent the musculoskeletal complains among adolescent performers.

\section{REFERENCES}

1. Armonienè J. (2007) Physical activity and health of schoolchildren (In Lithuanian). Pedagogika, 85: 116-121.

2. Barnekow-Bergkvist M, Hedberg G, Janlert U, Jansson E. (2001) Adolescent determinants of cardiovascular risk factors in adult men and women. Scand J Public Health, 29: 208-217.

3. Bragge P, Bialocerkowski A, McMeeken J. (2006) A systematic review of prevalence and risk factors associated with playing-related musculoskeletal disorders in pianists. Occup Med, 56: 28-38.

4. Brandfonbrener AG. (2003) Musculoskeletal problems of instrumental musicians. Hand Clin, 19(2): 231-239. 
5. Castelli DM, Hillman CH, Buck SM, Erwin H. (2007) Physical fitness and academic achievement in 3rd and 5th grade students. J Sport Exerc Psychol, 29: 239-252.

6. Čiužas R, Navickaitè J. (2008) Shift of student's assessment in conditions of change of educational paradigm (In Lithuanian). Pedagogika, 91: 53-59.

7. Donelly JE, Lambourne K. (2011) Classroom-based physical activity, cognition, and academic achievement. Prev Med, 52: S36-S42.

8. Emeljanovas A, Trinkūnienè L. (2011) Progress and achievements in physical education lessons from students' viewpoint (In Lithuanian). Filosofija. Sociologija, 22(4): 466-475.

9. Fedewa A, Ahn S. (2011) The effects of physical activity and physical fitness on children's achievement and cognitive outcomes. Res Q Exerc Sport, 82: 521-535.

10. Girdzijauskienė R. (2009) Achievements of junior school children in music and problem of evaluating them (In Lithuanian). Pedagogika, 94: 64-70.

11. Guan J, Xiang P, McBride R, Bruene A. (2006) Achievement goals, social goals and students' reported persistence and effort in high school physical education. J Teach Phys Educ, 25: 58-74.

12. Hills AP, Andersen LB, Byrne NM. (2011) Physical activity and obesity in children. Br J Sports Med, 45(11): 866-870.

13. James AR, Griffin L, Dodds P. (2009) Perceptions of middle school assessment: an ecological view. Phys Educ Sport Peda, 14(3): 323-334.

14. Ministry of Health of the Republic of Lithuania. (2012) Recommendations on pupils' physical activity and health (In Lithuanian).

$<$ http://www.ssus.lt/ssusadmin/kiti/lmitkcedit/uploads/files/Rekomendacijos\%20 mokini\%C5\%B3\%20fizinio\%20aktyvumo\%20ir\%20sveikatos\%20tema.pdf>

15. Mehrparvar AH, Mostaghaci M, Gerami RF. (2012) Musculoskeletal disorders among Iranian instrumentalists. Med Probl Perform Art, 27(4): 193-196.

16. General education plans of Middle and High school curricullum (2009) (In Lithuanian). <http://www.smm.lt/uploads/documents/ugdymo-planai/archyvas/2009-2011.pdf>

17. Lederman RJ. (2003) Neuromuscular and musculoskeletal problems in instrumental musicians. Muscle Nerve, 27(5): 549-561.

18. Nawrocka A, Mynarski W, Powerska-Didkowska A, Grabara M, Garbaciak W. (2014) Musculoskeletal pain among Polish music school students. Med Probl Perform Art, 29(2): 64-69.

19. Pate RR, Davis MG, Robinson TN, Stone EJ, McKenzie TL, Young JC. (2006) Promoting physical activity in children and youth: a leadership role for schools. A scientific statement from the American Heart Association Council on Nutrition, Physical Activity, and Metabolism (Physical Activity Committee) in collaboration with the Councils on Cardiovascular Disease in the Young and Cardiovascular Nursing. Circulation, 114(11): 1214-1224. 
20. Pečiuliauskienė P, Pipirienè V. (2008) The electronic student achievement assessment system in gymnasium: the opinion of teachers (In Lithuanian). Pedagogika, 90: 77-82.

21. Penney D, Brooker R, Hay P, Gillespiec L. (2009) Curriculum, pedagogy and assessment: three message systems of schooling and dimensions of quality physical education. Sport Educ Soc, 14(4): 421-442.

22. Polikoff MS, Porter AC, Smithson J. (2011) How well aligned are state assessments of student achievement with state content standards? Am Educ Res J, 48(3): 965-995.

23. Pühse U, Gerber M. (2005) International Comparison of Physical Education. Concepts, Problems, Prospects. Oxford: Meyer and Meyer Sport.

24. Roach AT, Beddow PA, Kurz A, Kettler RJ, Elliott SN. (2010) Incorporating student input in developing alternate assessments based on modified academic achievement standards. Except Children, 77(1): 61-80.

25. Salienè V. (2006) Assessment and self-assessment in Lithuanian language lessons: traditions and alternations (In Lithuanian). Pedagogika, 84: 114-119.

26. Sjöström M, Ainsworth B, Bauman A, Bull F, Craig C, Sallis J. (2005) Guidelines for data processing and analysis of the Intentional Physical Activity Questionnaire (IPAQ) - short and long forms. Karolinska Institute.

27. Sventickas A. (2001) Inspecting study outcomes and evaluation: Learners viewpoint (In Lithuanian). Pedagogika, 48: 60-73.

28. Toledo SD, Nadler SF, Norris RN, Akuthota V, Drake DF, Chou LH. (2004) Issues related to musicians. In Sports and performing arts medicine (No. 5). Arch Phys Med Rehabil, 85(1): S72-S74.

29. World Health Organization (2010). Global recommendations on physical activity for health. WHO Press: Switzerland.

30. Wilke C, Priebus J, Biallas B, Froböse I. (2011) Motor activity as a way of preventing musculoskeletal problems in string musicians. Med Probl Perform Art, 26(1): 24-29.

31. Zaborskis A, Raskilas A. (2011) Trends in school-aged children physical activity from 1994 to 2010 in Lithuania (In Lithuanian). Visuomenès sveikata, 3(54): $78-86$.

\section{Correspondence to}

Rita Gruodytè-Račienè, $\mathrm{PhD}$

Department of Health, Physical and Social Education

Lithuanian Sports University

Sporto 6, LT-44221, Kaunas, Lithuania

Tel.: +370 37302669

E-mail: rita.gruodyte@lsu.lt 